\title{
REVITALISASI MODAL SOSIAL MELALUI SINERGI TRIPLE HELIX DALAM PENANGGULANGAN PANDEMIC COVID-19
}

${ }^{1}$ Ambo Upe, ${ }^{2}$ Muhammad Rusli, ${ }^{3}$ Bahtiar, ${ }^{4}$ Sarpin, dan ${ }^{5}$ Darmin Tuwu

1-4Jurusan Sosiologi, FISIP UHO, ambo.upe@uho.ac.id

5Jurusan Ilmu Kesejahteraan Sosial, FISIP UHO

Jl. HEA Mokodompit, Kampus Bumi Tridharma Anduonohu, Kendari 93232

\section{RINGKASAN}

Pandemi Covid-19 telah berimplikasi terhadap berbagai aktivitas kehidupan manusia, tidak hanya pada aspek keseahatan, tetapi juga berimplikasi luas terhadap dimensi sosial, budaya, dan ekonomi. Karena itu, artikel ini bertujuan untuk memaparkan pentingnya adalah modal sosial dan sinergisitas triple helix (akademisi, pemerintah, dan pengusaha). Untuk mencapai tujuan tersebut, maka secara teknis metode yang digunakan adalah penyuluhan dan demonstrasi dengan menggunakan alat bantu seperti stiker, spanduk, dan baju kaos. Pada proses pelaksanaan juga akan dibagikan alat pelindung diri berupa masker. Aktivitas masyarakat semakin meningkat ketika kebijakan PSBB dicabut dan dinyatakan sebagai masa New Normal. Dalam aktivitas sehari-hari, seringkali dijumpai perilaku masyarakat yang tidak mengikuti protokol kesehatan, seperti yang terjadi pada masyarakat di Kelurahan Kambu. Perilaku ini terjadi karena disebabkan dua hal, yaitu adanya sikap kepasrahan (apatis) dan juga karena kurangnya kesadaran tentang bahaya yang dapat ditimbulkan dari perilaku di luar protokol kesehatan. Karena itu, diperlukan upaya untuk menyentuh domain pengetahuan (cognitive) dan rasa kepedulian bersama (affective) yang dilakukan dengan cara merevitalisasi modal sosial melalui sinergisitas UMKM (pelaku usaha percetakan), pemerintah, dan akademisi. Sinergisitas ini akan menghasilkan produk pengetahuan yang disebarkan melalui stiker, spanduk, baju kaos, dan masker. Dengan demikian, akan terbentuk pola kebiasaan baru (habits) dalam menanggulangi pandemi Covid-19.

\section{Kata kunci: Covid-19; New Normal; Social Capital; Triple Helix.}

\section{A. Analisis Situasi}

Virus korona pertama kali diidentifikasi oleh Organisasi Kesehatan Dunia (WHO) pada 31 Desember 2019. Virus yang muncul dari Kota Wuhan, Provinsi Hubei, Cina (Liu, et al., 2020), telah menyebar ke lebih dari 120 negara, dan pada 30 Januari 2020, itu menyatakan pandemi. Percepatan penyebaran juga mendorong WHO untuk secara resmi menetapkan Penyakit Virus Corona sebagai Keadaan Darurat Kesehatan Publik Tingkat Internasional. Berbagai fakta tersebut menunjukkan tingkat kegawatan dan kerumitan wabah ini. Pernyataan resmi WHO ini merupakan peringatan kepada seluruh pemerintah 
di semua negara agar meningkatkan kewaspadaan dalam rangka mengantisipasi pandemi ini karena Covid-19 sangat cepat menular (Yin \& Zeng, 2020).

Informasi tentang Covid-19 tersebar di akhir Desember 2019 dan seketika mengejutkan seluruh negara. Dunia kesehatan seolah disentak oleh kehadiran virus baru ini dengan gejala mirip influenza atau pneumonia yang menginfeksi saluran pernafasan sehingga menyebabkan sesak nafas. Berdasarkan data di berbagai media menunjukkan bahwa para penderita karena Covid-19 sangat cepat menular dan mematikan. Berdasarkan data epidemiologi diketahui terdapat $66 \%$ pasien memiliki hubungan dengan pasar seafood atau live market di Wuhan, Hubei Tiongkok (Huang, dkk., 2020).

Pandemi Covid-19 di berbagai belajan dunia, termasuk sejumlah daerah di Indonesia, sangatlah merisaukan masyarakat. Betapa tidak, wabah Covid-19 telah berdampak dalam berbagai sendi kehidupan, termasuk dalam aspek sosial ekonomi (Obi, et al., 2020), bahkan menyebabkan terjadinya cyber crime (Kashif, et al., 2020). Pasien yang terinfeksi umumnya memiliki gejala demam, namun, beberapa hanya merasa kedinginan dan nyeri pernapasan dengan batuk kering ringan, kelelahan, kesulitan bernafas, dan diare. Beberapa gejala ringan termasuk flu, dahak, dan kesulitan bernafas secara bertahap (Equatora et al., 2020). Penanganan Pandemi Covid-19 di Indonesia dipimpin langsung Pemerintah Pusat oleh Presiden RI melalui Gugus Covid-19.

Berdasarkan masalah tersebut, maka diperlukan upaya atau solusi untuk menyentuh domain pengetahuan (cognitive) dan rasa kepedulian bersama (affective) yang dilakukan dengan cara merevitalisasi modal sosial melalui sinergisitas UMKM (pelaku usaha percetakan), pemerintah, dan akademisi. Modal sosial (social capital) dimaknai sebagai serangkaian nilai dan norma yang hidup dalam kelompok atau komunitas sebagai pegangan bersama (Fukuyama, 2004). Nilai dan norma tersebut selanjutnya membangun cara berikap dan berprilaku untuk saling membantu dan bekerjasama. Hasbullah (2006) menekankan bahwa modal sosial ditandai oleh kecenderungan adanya saling berbagi kebaikan dan saling membantu (altruism) di antara berbagai anggota suatu kelompok atau masyarakat. Sinergisitas ini akan menghasilkan produk pengetahuan yang 
disebarkan melalui stiker, spanduk, baju kaos, dan masker. Dengan demikian, akan terbentuk pola kebiasaan baru (habits) dalam menanggulangi pandemi Covid-19.

\section{B. Metode Pelaksanaan}

Untuk mencapai keberhasilan kegiatan ini, maka secara teknis metode yang digunakan adalah penyuluhan dan demonstrasi dengan menggunakan alat bantu seperti stiker, banner, masker, hand sanitizer, dan spanduk. Pada proses pelaksanaan juga akan dibagikan alat kesehatan berupa masker dan hand sanitizer. Untuk itu, diperlukan beberapa tahap yang meliputi tahapan persiapan, pelaksanaan, dan evaluasi.

1. Tahap Persiapan. Pada tahap ini tim PKM Internal UHO membangun komunikasi dengan pelaku usaha (mitra) dan pemerintah kelurahan. Pada tahap ini dilakukan menandatanganan surat pernyataan oleh pihak mitra, dalam hal ini UMKM percetakan dan pemerintah kelurahan.

2. Tahap pelaksanaan. Pada tahap ini tim PKM Internal UHO bersama mitra 1 (Percetakan) melakukan desain bahan penyuluhan berupa stiker dan spanduk. Pada tahap ini juga mitra 2 (pemerintah kelurahan) memfasilitasi tim pelaksana PKM Internal UHO dengan masyarakat Kelurahan Kambu untuk mengikuti proses penyuluhan dan demonstrasi perilaku hidup sehat sesuai standar protokol Covid-19.

3. Tahap evaluasi. Tahapan ini merupakan tahapan akhir sebelum Tim PKM Internal UHO menyusun laporan akhir. Tahapan ini sangat penting untuk mengetahui sejauhmana keberhasilan dan hambatan yang dihadapi oleh khalayak untuk mendapatkan tindakan lebih lanjut.

\section{Hasil dan Pembahasan}

Pandemi Covid-19 merupakan problematika dalam dunia kesehatan yang berimplikasi nyata dalam berbagai dimensi kehidupan sosial, diantaranya: dimensi kesehatan, psikologis, dan sosial ekonomi. Berbagai dampak yang dirasakan oleh masyarakat di Indonesia pada dasarnya memiliki kesamaan dengan apa yang dirasakan oleh masyarakat di berbagai belahan dunia yang tengah dilanda wabah Covid- 19 . 
Keadaan demikian telah menyebabkan goncangan dan kerentanan sosial di berbagai negara. Sebagai upaya dalam memulihkan goncangan tersebut, maka dibutuhkan revitalisasi modal sosial (social capita). Sosiolog asal Prancis, Pierre Bourdieu dalam karnyanya yang berjudul The Forms of Capital (1986) menyebutkan bahwa modal sosial merupakan komponen penting dalam membangun situasi dalam masyarakat.

Dalam artikel ini, revitalisasi modal sosial (social capita) merujuk pada tipologi modal sosial sebagimana dimaksudkan oleh Woolcock (1998), meliputi bonding social capital, bridging social capital, dan linking social capital. Dari tiga tipe ini selanjutnya dielaborasi dengan konsep triple helix sebagaimana dijelaskan oleh Etzkowitz dan Leydesdorff (1998), meliputi relasi antara University, Industry, dan Government. Ketiga tipologi modal sosial tersebut diuraikan sebagai berikut.

\section{Revitalisasi Bonding Social Capital}

Modal sosial bonding menggambarkan tipe ikatan sosial yang terbangun dalam konteks pemikiran, persepsi, nilai, dan kultur yang sama (homogeneity). Karena itu, tipe modal sosial ini lebih berorientasi ke dalam (inward looking) daripada orientasi ke luar (outward looking). Kekuatan modal sosial pada tipe bonding lebih spesifik hanya dalam dimensi kemenyatuan internal kelompok sosial tertentu saja. Untuk itu, setiap unsur atau anggota kelompok atau komunitas dapat memanfaatkan energi ini dalam bentuk support dalam segala aktitivitas sosialnya.

Secara praktis, revitalisasi bonding social capitalakan melahirkan cara pandang atau persepsi dalam diri individu akan identitas yang sama, misalnya perasaan sedaerah, sesuku, seagama, sebangsa sehingga menciptakan rasa kewajiban moral untuk saling membantu satu sama lain. Dalam konteks penanggulangan Covid-19, sering ditemukan munculnya jejaring sosial dan sukarelawan. Masyarakat menunjukkan rasa tanggap tinggi dalam melindungi komunitas. Sesama warga memberikan dukungan bagi komunitas yang terdampak COVID-19. Mereka menggalang solidaritas sosial agar warga dapat menyumbang apapun untuk bantuan darurat. 


\section{Revitalisasi Bridging Social Capital}

Selain diperlukan revitalisasi modal sosial internal, juga diperlukan revitalisasi modal sosial yang berfungi untuk menjembatani atau menghubungkan (bridging social capita). Revitalisasi modal ini merupakan upaya membangun kekuatan dan energi melalui hubungan sosial antara berbagai unsur atau kelompok sosial yang berbeda (heterogeneity). Kekuatan tipe modal sosial ini dibangun berdasarkan norma dan kepercayaan secara turun temurun sebagai pegangan bersama. Energi bridging social capital membuka ruang terbuka selebar-lebarnya untuk memaksimalkan potensi yang dimiliki baik dari dalam (interna) maupun dari luar (external) suatu kelompok, komunitas, sector, dan sebagainya. Adapun prinsip dasar yang mendasari revitalisasi bridging social capitalyaitu universal tentang nilai-nilai kemajemukan, kebersamaan, dan kemanusiaan (Hasbullah, 2006).

Modal sosial bridging dapat berkontribusi dalam kehidupan sosial khususnya dalam menjembatani berfungsinya modal lainnya. Selain itu, revitalisasi bridging social capital dapat membangun dan mengembangkan hubungan sosial antar berbagai kelompok sosial lainnya. Revitalisasi bridging social capital dalam penanggulangan Covid-19 dapat dilakukan dalam konteks yang luas, misalnya hubungan antar bidang, sektor, instansi, dan lembaga, baik lembaga pemerintah maupun non pemerintah. Dengan demikian, perspektif yang perlu dibangun adalah cara pandang keluar (outward looking) yang dimaksudkan untuk menjalin koneksi dan jaringan kerja serah dalam penangan pandemic Covid-19 secara menyeluruh, tanpa adanya sekat dan ego sektoral.

\section{Revitalisasi Linking Social Capital}

Penanggulangan bersama pandemi Covid-19 tidak hanya cukup dengan menguatkan solidaritas internal dan eksternal, melainkan akan lebih efektif jika dibangun pola hubungan vertical hirarkis. Karena itu, diperlukan revitalisasi modal sosial ke arah linking social capital. Dalam konteks ini, penangan Covid-19 bukan hanya menjadi domain pemerintah pusat, tetapi juga menjadi urusan pemerintah dari berbagai tingkatan. Dengan demikian, revitalisasi modal sosial melalui sinergi triple helix akan menjadi kekuatan sosial dalam melawan Covid-19 yang meliputi kepercayaan (trust), norma- 
norma (norms) dan jaringan (network) yang saling terkait satu sama lain. Sinergi modal sosial dalam mekanisme kerja triple helix akan menghasilkan solidaritas berupa kepedulian sosial, rasa tanggung jawab, dan kerjasama. Kolaborasi ketiga tipologi modal sosial diilustrasikan dalam bagan berikut.

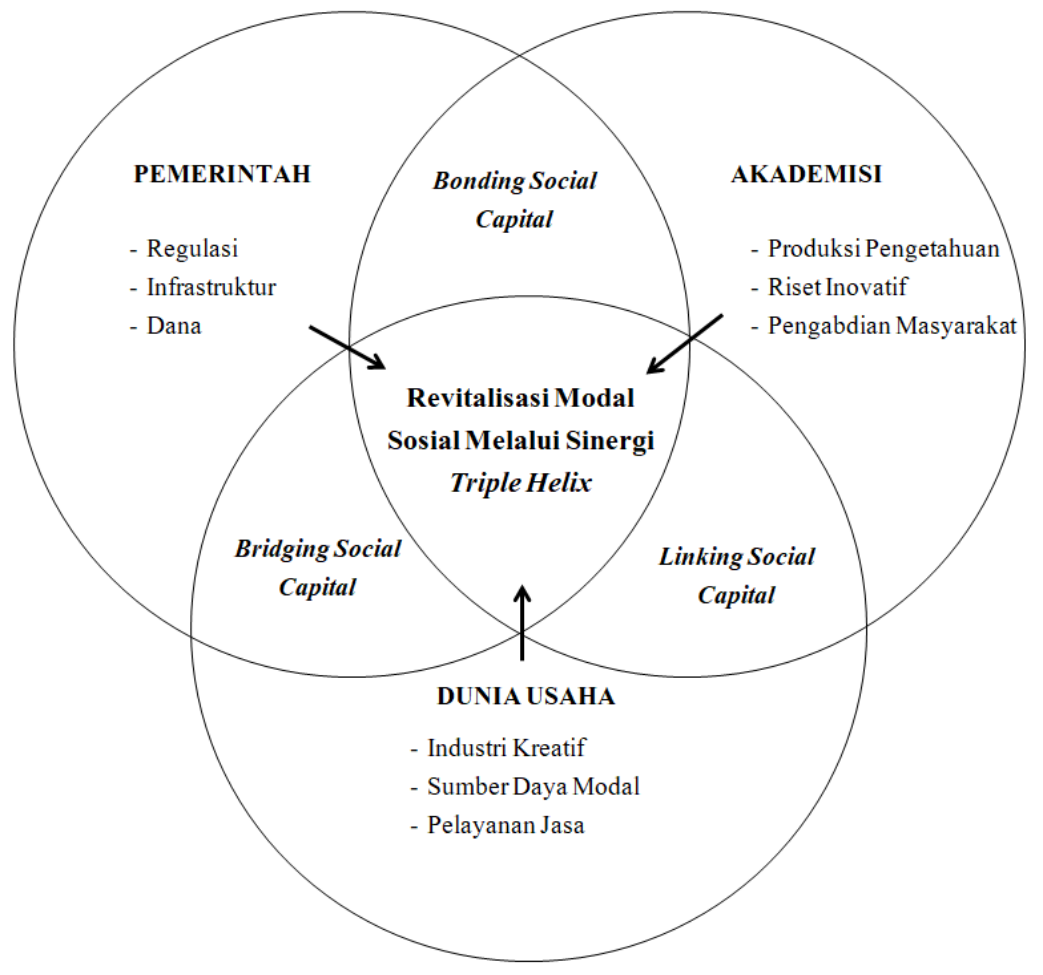

Diagram Revitalisasi Modal Sosial Melalui Sinergi Triple Helix

Efektivitas penanganan Covid-19 akan tercapai maksimal dengan melibatkan berbagai unsur, bukan hanya pemerintah, tetapi juga dunia kampus dan dunia usaha. Inilah konsep triple helix sebagaimana dimaksudkan oleh Etzkowitz dan Leydesdorff (2000). Pemerintah (government) merupakan suatu organisasi besar yang memiliki sistem, struktur dan fungsi diselenggarakan berdasarkan konstitusi dan kebijakan dalam mewujudkan cita-cita dan tujuan negara. Dalam konteks ini, pemerintah sangat berperan dalam menyediakan regulasi, infrastruktur, dan pendanaan. Sementara itu, dunia kampus sebagai suatu komunitas ilmuwan dalam institusi pendidikan tinggi dan lembaga riset berperan penting dalam memproduksi pengetahuan, pengembangan riset inovatif, dan pengabdian kepada masyarakat. Singkatnya, kampus memegang kontribusi penting 
dalam menghasilkan inovasi untuk mengkonsturksi masyarakat berbasis ilmu pengetahuan. Universitas dapat memberikan masukan, bimbingan, sosialisasi, penyuluhan seputar pandemi Covid-19. Demikian pula pentingnya peran dunia usaha (business) dalam menciptakan industri kreatif, sumber daya modal, dan pelayanan jasa.

Implementasi triple helix menitikberatkan pada aktor yang selalu berinteraksi secara timbal balik dalam mengkonstruksi ruang pengetahuan (knowledge spaces). Sinergi ketiga aktor dapat berjalan jika memiliki visi, misi, dan tujuan yang sama dalam penaggulangan Covid-19. Karena itu, pola sinergi antara dunia kampus, dunia usaha, dan pemerintah adalah pola relasi resiprokal. Sinergi ketiga aktor utama ini akan membangkitkan kekuatan masyarakat untuk mengelola potensi yang dimiliki dalam penanggulangan Covid-19. Kekuatan yang dimiliki masyarakat dapat berupa sumber daya sosial, yang dapat berupa nilai, norma, kepercayaan yang kemudian akan membentuk berbagai jaringan sosial. Coleman (1990) menjelaskan bahwa nilai-nilai sosial akan menjadi panduan bagi sekelompok orang untuk berinteraksi. Seperti dikemukaan Fukuyama (2002), karena nilai dan norma yang berakar dari budaya dan ajaran agama akan mendorong masyarakat untuk bekerjasama, saling membalas dalam hal kebaikan, memperkuat suatu kelembagaan sosial.

\section{Penutup}

Berdasarkan pelaksanaan kegiatan pengabdian melalui Program Kemitraan Masyarakat Internal (PKMI) sebagaimana yang diuraikan di atas, maka dapat ambil beberapa kesimpulan sebagai berikut:

1. Sikap masyarakat dalam menanggapi pandemi Covid-19 cukup beragam, meliputi sikap kritis, yaitu masyarakat yang tidak atau kurang percaya terhadap keberadaan Covid-19. Selain itu, sebagian masyarakat bersikap apatis yaitu masyarakat yang tidak peduli dengan Covid-19. Meski demikian, masih terdapat kelompok masyarakat yang responsive, dimana kelompok ini memiliki pengetahuan memadai tentang Covid-19 dan memiliki kepedulian untuk mencegah penyebarannya. 
2. Sinergisitas triple helix meliputi pemerintah, akademisi, dan dunia usaha menjadi modal sosial yang sangat penting difungsikan. Melalui peran bersama ini diharapkan berjalan secara sinergis dengan funsginya masing-masing.

3. Perlunya mengintensifkan sosialisasi dan penyuluhan tentang upaya menghadapi pandemic Covid-19 di berbagai bidang, tidak hanya dalam aspek kesehatan, tetapi juga aspek sosial ekonomi, budaya, dan agama.

\section{E. Ucapan Terima Kasih}

Melalui kesempatan ini kami tim pengabdian kepada masyarakat mengucapkan terima kasih kepada Bapak Rektor Universitas Halu Oleo (UHO) melalui Lembaga Penelitian dan Pengabdian kepada Masyarakat (LPPM) yang telah memfasilitasi biaya pelaksanaan melalui Dana DIPA Universitas Halu Oleo Nomor: SP DIPA023.17.2.677510/2020.

\section{Daftar Pustaka}

Coleman, James S. (1990). Foundations of Social Theory. Cambridge, Mass: Harvard University Press.

Equatora, Muhammad Ali; Upe, Ambo; Sumandiyar, Adi; Rusli, Muhammad. (2020). The Use of an Advanced Multi-systemic Approach by Social Workers in Handling Corona Virus. Journal of Advance Research in Dynamical \& Control Systems, Vol. 12, No. 5.

Fukuyama, Francis. (2002). Social Capital and Development: The Coming Agenda. SAIS Review 22.1 23-37.

Fukuyama, Francis. (2014). The Great Disruption: Hakikat Manusia dan Rekonstitusi Tatanan Sosial. Yogyakarta: Penerbit Qalam.

Hasbullah, Jousairi. (2006). Social Capital, Menuju Keunggulan Budaya Manusia Indonesia. Jakarta: MR-United Presss.

Huang. (2020). Clinical Features of Patients Infected With 2019 Novel Coronavirus in Wuhan, China. The Lancet.

Etzkowitz, H. and Leydesdorff, L. (1998). The Endless Transition: A Triple Helix of University-Industry-Government Relations, Introduction to a Theme Issue. Minerva, Vol. 36, 203-208.

Etzkowitz, H. and Leydesdorff, L. (2000). The Dynamics of Innovation: from National Systems and "Mode 2" to a Triple Helix of University Industry-Government Relations. Research Policy, Vol. 29, 109-123. 
Kashif, M., Rehman, A.U., Javed, M.K., \& Pandey, D. (2020). A Surge in Cyber-Crime during COVID-19. Indonesian Journal of Social and Environmental Issues (IJSEI), 1(2), 48-52.

Liu, W., Tao, Z. W., Wang, L., Yuan, M. L., Liu, K., Zhou, L., Ming, Y. (2020). Analysis of Factors Associated with Disease Outcomes in Hospitalized Patients with 2019 Novel Coronavirus Disease. Chinese medical journal.

Obi, S. E., Yunusa, T., Ezeogueri-Oyewole A. N., Sekpe, S. S., Egwemi, E., \& Isiaka, A. S. (2020). The Socio-Economic Impact of Covid-19 on The Economic Activities of Selected States in Nigeria. Indonesian Journal of Social and Environmental Issues (IJSEI), 1(2), 39-47.

Woolcock, M. (1998): Social Capital and Economic Development: Towards a Theoretical Synthesis and Policy Framework, Theory and Society, Vol. 27, 151 - 208.

Yin, X., \& Zeng, L. (2020). A study on the Psychological Needs of Nurses Caring for Patients with Coronavirus Disease 2019 from the Perspective of the Existence, Relatedness, and Growth Theory. International Journal of Nursing Sciences. 